\title{
How is the impact of assessment for learning (AfL) on mathematics learning in elementary schools?
}

\author{
Eri Yusron*, Sudiyatno Sudiyatno \\ Universitas Negeri Yogyakarta. Jalan Colombo No. 1, Yogyakarya 55281, Indonesia \\ * Corresponding Author. E-mail: eyusron98@gmail.com
}

Received: 3 October 2020; Revised: 23 October 2020; Accepted: 2 December 2020

\begin{abstract}
This study aims to describe the effectiveness of the Assessment for Learning (AfL) in improving the quality of learning and mathematics learning outcomes in elementary schools. This study used a quasiexperimental method with a non-equivalent control group design. The instrument used was a test instrument with good validity, reliability, difficulty level, and different power. The non-test instrument was valid and good. Data analysis was performed using descriptive statistics, mean difference test, and variance difference test on AfL learning outcomes. The results showed that the effectiveness of learning in implementing AfL could be influenced by assessment preparation, student involvement, and follow-up assessment. The quantitative analysis results show that AfL can improve student learning outcomes; there is no mean-variance in AfL learning outcomes; There are differences in learning outcomes, and there are no variants in learning with AfL and conventional assessments. Suggestions, it is necessary to plan the assessment process, diagnose student needs and abilities. Moreover, there is a need for follow-up and feedback to see achievements.
\end{abstract}

Keywords: Assessment for Learning, Mathematics Learning, Elementary School.

How to Cite: Yusron, E., \& Sudiyatno, S. (2021). How is the impact of Assessment for Learning (AfL) on mathematics learning in elementary schools?. Jurnal Prima Edukasia, 9(1), 75-84. doi:https://doi.org/10.21831/jpe.v9i1.34865

\section{Introduction}

Improving Indonesian education must start by improving the learning process in the classroom because the learning process in education is the main activity in improving education quality. Learning process activities are essential and become the focus. Because learning is a significant factor in improving education, the learning process must be more effective in increasing students' potential. The learning process must continue to be addressed and continuously improved. As mandated in the Minister of Education and Culture Regulation Number 23 of 2016 that in improving education, it is necessary to improve the learning process through an assessment or assessment process to produce an evaluation of the learning program. Assessment is an integral part of education; assessment in education is an effort to improve education quality.

This opinion shows that assessment is an essential part of the learning process as well as education. This view is the same as Harlen (2007) expressed that assessment is an essential part of education. Then, the importance of assessment in the learning process was arrived at by Mardapi (2017) that increasing the learning process's effectiveness is to carry out an integrated and holistic assessment process with the learning process. These views show the importance of the assessment process in improving the learning process and adjusting it as needed.

Assessment is essential in the learning process, but the facts in the field are based on research results that teachers have difficulty carrying out the overall assessment process (Enggarwati, 2015). This is indicated by the lack of practice or training in the assessment process and the large number of students being part of the teacher's obstacles due to the difficulty in conducting the assessment process. The current assessment of learning still puts forward the final assessment without considering process assessment. The final assessment is only limited to the final examination of learning and without any feedback for learning improvement. The results of other studies show that summative assessment practice is an assessment practice that is often carried out periodically. While in the practice of formative assessment, it is not too optimal in its implementation because there are three factors, namely methods, utilization of results, and students in learning mathematics (Mansyur, 2013). 
Jurnal Prima Edukasia, 9 (1), 2021 - 76

Eri Yusron, Sudiyatno Sudiyatno

Pre-research observations were carried out to see the assessment process in high-grade mathematics subjects. This observation was carried out in grade 4 and grade 5 at SDIT Salman Al-Farisi 2 in odd semester learning in the 2019/2020 school year. The observations show that (1) the assessment process is always planned; the planning is done by making RPP (Learning Process Plan). (2) assessing the learning process is done by giving quizzes or questions in the form of PG (multiple choice) or essays. (3) assessment in the form of observation is rarely done. (4) assessment rarely involves students, parents, or teachers. (5) The assessment is always carried out in the classroom (6) the teacher's difficulties in the assessment are too many aspects and inefficient the assessment process. (7) further assessment results are only as information on learning outcomes. The results of the pre-research findings indicate that in mathematics learning, especially in elementary schools (SD), the assessment process is always planned and occurs in the classroom. However, the results of the assessment are only used as information material, not used as material for improving learning.

The findings indicate that in carrying out the assessment process, it should not only focus on student learning outcomes (assessment of learning). However, learning assessments must also become the basis of information for teachers and students as material for improving learning by conducting assessments in the learning process. or assessment for learning (AfL) to be used as a material in evaluating learning. The difference between the current (conventional) assessment and the AfL lies in the identification process, improving learning and assessment feedback. Then AfL is also considered more appropriate in improving the learning process to make it more effective. Therefore, in learning mathematics in elementary school, the assessment process with the AfL model is essential to be applied as a means of information learning needs and learning improvement processes so that the learning process is more effective and meaningful.

Conventional assessment is an assessment that is often carried out by the teacher. That is an assessment carried out at the end of the lesson by giving a test. The results of the assessment are used as an evaluation of learning. Conventional assessments are assessment formative. Conventional assessments are usually carried out at the end of learning, midterm, and end of the semester. This assessment only refers to the final assessment and does not provide information about the learning process.

The Assessment for Learning model is a formative assessment when it refers to the actual purpose of the assessment, and AfL prioritizes design and practice to promote student learning (Black \& Wiliam, 2005). Pearson Education (Mansyur, 2013) explains that Assessment for Learning is a collaborative process between teachers and students and students and students involved in making learning structures. This shows that the assessment for learning model is an assessment model that aims to improve the learning process. The assessment results become feedback and become the basis for improving the learning process based on student needs.

Apart from the theory which explains that AfL can increase the effectiveness and improve learning, several studies have proven that AfL can improve the learning process for the better. Research conducted by Mansyur (2011) shows that the application of AfL can increase the effectiveness of learning in junior high schools (SMP) in mathematics. The research conducted by Paryanto \& Sudiyatno (2011) shows that the implementation of the AfL model in the learning process of machining practices effectively improves the quality of learning machining practices for students.

Results of a systematic review by Heitink et al. (2016) recommend that in preparing lessons with AfL, many specific preparations are needed, but this must be implemented to see improvements in implementing the AfL. This shows that there needs to be a study in implementing the AfL model in learning. This is also confirmed by Baas et al. (2015) that it is essential to apply AfL to learning to control student development. Apart from that, the results of other research indicate that if AfL is applied in learning, it will provide positive changes to improve the assessment process (DeLuca et al., 2015).

Previous research findings indicate that AfL is effective in learning mathematics. AfL is effective in practical learning. AfL is recommended to be applied to get more study. AfL can provide an overview of student development, and AfL can also positively influence carrying out the assessment process. This shows the importance of a study that looks at the application of AfL in mathematics learning and how AfL affects student learning outcomes.

The results obtained by Indonesian students are still unsatisfactory. Then the assessment carried out by the teacher has less influence to improve learning, which has not been implemented. The assessment carried out by the teacher at this time is still summative, which only sees the result of learning 
Jurnal Prima Edukasia, 9 (1), 2021 - 77

Eri Yusron, Sudiyatno Sudiyatno

without any feedback. These things need to be improved to improve the quality of learning and learning outcomes that will impact students. Therefore, it is necessary to make efforts of the teacher to overcome this.

The previous results that have been described indicate that the AfL model can increase the effectiveness of the learning process and learning outcomes. However, will the AfL model's application be able to increase the effectiveness and improvement of learning in elementary schools in mathematics, especially for the upper class? Therefore, it is necessary to research to produce an overview of the application of AfL in the process of increasing the effectiveness of the special learning process in primary schools.

\section{Method}

The research method used in this research is the experimental method. The research design used was quasi-experimental (quasi-experimental). The research will be conducted in grade 4 SDIT Salaman Al-Farisi and SDIT Salman Al-Farisi 2. This research was conducted in November-December 2019 in semester one or odd semester. In this research, data collection will be carried out using tests and nontests. Data retrieval by tests was carried out through pretest and post-test. Data collection was carried out at the beginning of the study and the end of the study. Retrieval of non-test data with observations and questionnaires, observational data collection was carried out during the learning and research process, and data collection using questionnaires was carried out at the end of the study.

This research uses the right instruments. The content validity results showed that the test instrument to be used had an average validity index of Aiken (1980) with a value of 0.763 . The test results were analyzed using item response theory (IRT) (Azwar, 2011; Retnawati, 2016), where the test instrument is divide into two parts, namely 15 items for dichotomous and eight items for polytomous (PCM). The instrument trial analysis results showed that ten dichotomous items had the right difficulty level and differentiation characteristics, while the polytomous items had five items that had acceptable difficulty levels. The analysis of the test instrument's characteristics showed that for the dichotomous item, the reliability estimate was 0.832 , while for the polytomous item 0.700 . Five experts validated this result as validators to assess the instrument's appropriateness based on the aspects that have been determined in each non-test instrument. Overall, the non-test instruments validated by five validators show that these instruments can be used to achieve this study's objectives with a little revision or input from each instrument's validator.

Descriptive data analysis was carried out on data from the findings of the observation instruments and questionnaire instruments. This descriptive analysis technique uses analysis techniques from Miles et al. (1994) and descriptive statistical analysis techniques. Hypothesis testing can be done parametrically if the assumption tests are met, but if the assumptions are not met, it is done nonparametrically. To test the hypothesis parametrically in this study was carried out by using Paired t-test, Independent sample t-test, Chi-square test, F-test (Bluman, 2009), (Larson \& Farber, 2019) and nonparametric Wilcoxon (sample dependent), Mann-Whitney U (independent sample), (Lestari et al., 2015). Bonett (variance test) (Bluman, 2009).

\section{Results and Discussion}

Research on the effect of Assessment for Learning (AfL) in improving learning outcomes and the learning process's effectiveness. The process of learning mathematics with the AfL model assessment in elementary schools has its characteristics. These characteristics are described in each part of the activity. The learning process is divided into three activities: preliminary activities, core activities, and closing activities.

In preliminary learning activities with AfL assessments, there are several activities carried out, such as sharing learning objectives and helping students understand learning objectives. In applying AfL in mathematics learning, core activities include identifying abilities, identifying achievements, improvement of achievement, and feedback on assessment results.

The closing activity on learning with the AfL model assessment is carried out by delivering information on achievement progress, taking follow-up actions, and planning further learning. 
Jurnal Prima Edukasia, 9 (1), 2021 - 78

Eri Yusron, Sudiyatno Sudiyatno

Effectiveness of Learning with AfL

The results showed that learning mathematics with an assessment using the AfL model has good learning effectiveness. The effectiveness of learning is reflected in planning activities, learning processes, and follow-up activities. There are preparations for learning in planning activities such as making lesson plans, preparing teaching materials, developing practice questions, and making assessment instruments and their assessment formats. Then in the learning process, the educator starts the learning process with appreciation, invites students to be active in learning, learning according to lesson plans, fosters learning motivation, utilizes learning facilities, and performs achievement analysis. In follow-up activities, educators make improvements, identify student abilities, and plan further learning.

Table 1. Percentage effectiveness of Learning with AfL

\begin{tabular}{clc}
\hline \multicolumn{1}{c}{ Activities } & \multicolumn{1}{c}{ Aspects } & Effectiveness \\
\hline Planning & Lesson plan (RPP) & $83,33 \%$ \\
& Teaching materials (books and worksheet.) & \\
& Quiz & \\
& Assessment sheet (knowledge, attitude, and skils) & \\
Learning Process & Apersment Format & $77,08 \%$ \\
& Students actively learning & \\
& Motivated students & \\
& Learning situation & \\
& Students involved in assessment & \\
& Learning according to RPP & \\
& Learning and assessment facilities & \\
& Achievement analysis and learning tools & \\
& Improving learning & \\
& Identify students' abilities & \\
& Plan learning improvements & \\
\hline
\end{tabular}

Table 1 shows the percentage of the effectiveness of learning mathematics with the AfL assessment. Planning activities planned for learning mathematics has the highest percentage of learning process activities and learning follow-up activities. The planning in making lesson plans, preparing teaching materials, preparing quizzes, assessment sheets, and the format had an achievement percentage of $83.33 \%$. Meanwhile, the learning process activities only reached $77.08 \%$. Continued learning gave an achievement percentage of $56.25 \%$. This shows that preparation and deep application are not very good.

The results showed that learning mathematics with an assessment using the AfL model has good learning effectiveness. The effectiveness of learning is reflected in planning activities, learning processes, and follow-up activities. There are preparations for learning in planning activities such as making lesson plans, preparing teaching materials, developing practice questions, and making assessment instruments and their assessment formats. Then in the learning process, the educator starts the learning process with appreciation, invites students to be active in learning, learning according to lesson plans, fosters learning motivation, utilizes learning facilities, and performs achievement analysis. In follow-up activities, educators make improvements, identify student abilities, and plan further learning.

The effectiveness of good mathematics learning occurs because of the use of the AfL model assessment. In carrying out the learning process with the AfL model assessment, planning is necessary (Kurniawan, 2016). Planning for the AfL model assessment is carried out by preparing learning tools such as lesson plans, practice questions, assessment sheets, and assessment formats. Preparation of learning tools prepared by educators properly will make learning more effective (Rohmawati, 2015), (Rosida et al., 2018), (Sutarto, 2017). Findings at the planning stage and related theories suggest that assessment with the AfL model can make math learning effective.

Then the effectiveness of learning occurs because of the learning process. Learning will be useful if the assessment method uses an assessment method that suits student needs (Paolini, 2015). The characteristics of AfL allow an assessment to be carried out according to the needs and abilities of 
Jurnal Prima Edukasia, 9 (1), 2021 - 79

Eri Yusron, Sudiyatno Sudiyatno

students (Black \& Wiliam, 2005). Learning mathematics with the AfL model assessment makes this possible because at the beginning of learning, identifying students' needs and abilities in learning (Atkin \& Coffey, 2003), (Black \& Wiliam, 2018). This is the learning process using the AfL model assessment. The assessment process with the AfL model in mathematics learning will suit students' needs and abilities because there is a process of identifying learning needs for students, which makes the learning process effective.

The results showed that learning tailored to the needs of students increased motivation. Student motivation to learn will make the learning process effective (Zajda, 2018). The research findings show that learning with AfL creates an active learning process because students are actively involved in the learning process. Students who are active in the learning process will make the learning process effective (Jeyaraj, 2019). Then the AfL model involves students in the learning assessment process (Atkin \& Coffey, 2003), (Black \& Wiliam, 2005) so that this shows that students are involved in learning. Involving students in learning makes the learning process effective (Jeyaraj, 2019). The AfL model involves students in the learning process, from the involvement makes students active, and when students are active in the learning process, it will foster student learning motivation.

Then the findings in learning with the AfL model assessment also led to an analysis of student achievement. Analysis of student achievement is carried out to assess and improve learning (Black \& Wiliam, 2005). Learning improvement is based on analyzing student needs and student abilities so that these improvements are appropriate to make learning improvements (Kurniawan, 2016), (Winarno et al., 2019). So the learning process using an assessment model reviewed in the learning process will motivate students, involve students in assessments, make students active, learn according to plan, and the existence of an analysis of achievement makes the learning process effective. These things foster an effective learning process.

The effective learning process is reflected in the follow-up activities in learning using the AfL assessment model. In learning with the AfL model assessment, there are activities to identify abilities and achievements (Black \& Wiliam, 2005), (Triwiyono, 2017). The research findings indicate that there is an identification of achievement. Then from the results of the identification, learning improvements were made. Improvements in learning carried out in learning with the AfL model are not repaired without foundation. The improvement in learning is based on the results of identifying abilities and achievements. Improvements like this will help students make improvements because each student requires different treatment to make improvements to create an effective learning process.

The learning process using the AfL model assessment is not only limited to improving learning, but the AfL model assessment also facilitates follow-up to the next lesson planning (Black \& Wiliam, 2005), (Chappuis \& Stiggins, 2002). This occurs in the research findings results. The results of the research findings indicate that the learning model using the AfL assessment model contains further learning planning activities. The next lesson planning activity will foster an effective learning process in subsequent learning because the planner will provide findings that can base further learning. These findings include the need for students to learn, appropriate learning tools and learning models, and strategies to improve learning.

Math learning outcomes with AfL

The analysis results that have been carried out on this hypothesis indicate that there are pretest results that are smaller than the post-test results in the experimental class. This shows an increase in the average learning outcomes after learning with the application of AfL. The results of other analyzes show that there is no difference in variance between the pretest and post-test results. It can be interpreted that AfL learning does not affect the variance of pretest and post-test results.

The findings regarding learning outcomes indicate that learning with the AfL assessment model in mathematics in elementary schools affects student learning outcomes, and there is no difference in the variance of learning outcomes before and after learning with the AfL assessment model. The results of the analysis explain that there is a relationship between initial abilities and learning outcomes. Initial abilities need to be possessed by students because they are the basis for improving learning outcomes(Arifin et al., 2020), (Clarke et al., 2015). Some research results show an effect of initial ability on learning outcomes (Hevriansyah \& Megawanti, 2017). Then about the variance of learning outcomes, it turns out that the variance of learning outcomes is influenced by the provision of treatment in the 
Jurnal Prima Edukasia, 9 (1), 2021 - 80

Eri Yusron, Sudiyatno Sudiyatno

mathematics learning process (Rahmawati, 2018). This shows that the initial ability can affect learning outcomes with different variances depending on the treatment.

Learning outcomes are not only influenced by initial abilities, but other factors affect both interest, motivation, or learning strategies (Astuti, 2015), (Irawati, 2015), (Mulyono, 2017). It sees at the AfL learning process on learning outcomes because of lessons, practice questions, learning improvements, and learning motivation. Good learning outcomes arise because there is learning preparation (Black \& Wiliam, 2018). Black \& Wiliam (1998), Benkirane et al. (2019) suggest that conducting an assessment in learning requires preparation. This preparation is carried out by preparing an outline (Kurniawan, 2016) and conveying learning objectives to understand the goals they will achieve. Getting effective learning outcomes requires good learning preparation.

Through the exercises, these questions resulted in satisfying learning outcomes (Khoiriah et al., 2020; O'Leary, 2017; Widyastuti Nurharyanto \& Retnawati, 2020). The goal of improving learning outcomes with the AfL assessment provides an assessment by identifying the needs and abilities of students. The identification results became the basis for improvement, the improvements made by practicing questions (Yusron et al., 2020). Exercise questions carried out to improve learning are tailored to the abilities and needs of students by identification. This is proven by an increase thanks to questions, the results of student tests before learning with AfL, and an increase in learning outcomes where students can answer questions after doing the exercises. When the question exercises occur, students learn to identify needs, which results from identification become the basis for improving learning outcomes (Widyastuti Nurharyanto \& Retnawati, 2020). The improvement and identification of student needs are proven to equalize the mean-variance of learning outcomes so that it shows a good equalization of treatment from the day of the learning treatment with AfL.

The research findings indicate that students who are enthusiastic about achieving learning goals foster high motivation to learn to achieve learning goals. This motivation helps students improve learning outcomes (Retnawati et al., 2019). Learning motivation can influence and have a relationship with student learning outcomes (Sulistiyarini \& Sukardi, 2016). Students active in learning give students many opportunities to make improvements and identify abilities. Moreover, active learning will also improve learning outcomes directly (Baharun, 2015). Through this, students can tie learning outcomes.

In assessment learning with the AfL model, students are also invited to provide feedback on learning. These findings turned out to be able to improve student learning outcomes. This is in line with research conducted by Van der Kleij, Feskens, and Eggen (in Leeuwenkamp et al., 2019) that feedback in learning will improve student learning outcomes.

The learning process with the AfL assessment can improve mathematics learning outcomes, and there is no significant diversity in learning outcomes. The learning outcomes increase because, in the learning process, students are facilitated to identify themselves, improve learning with practice, and foster enthusiasm for learning. This process is contained in learning with the AfL assessment model to improve student learning outcomes.

\section{Comparison of AfL learning outcomes with Conventional}

The statistical test results show a difference in the mean results between the post-test in the experimental class and the post-test in the control class. The post-test average in the experimental class is 73.45 , and the post-test average in the control class is 64.52 . This shows that the average result of learning with AfL is different from learning through conventional assessment, and the average result of learning with AfL is more significant than learning through conventional assessment. The results of other statistical tests show that there is no difference in variance between the experimental class and the control class in the post-test results. The experimental class's post-test variance was 125,760 , and the post-test variance of the control class was 125,981 . This shows that there is no difference in variance in AfL learning outcomes and learning through conventional assessment.

Testing the hypothesis indicates that there are differences in learning outcomes in applying AfL with conventional assessments, and there is no difference in variance in learning outcomes. The difference in learning outcomes is seen because the AfL assessment emphasizes the process of improvement (Taras, 2010). Providing facilities to increase student potential or improve things that students need to be improved / not mastered (Black \& Wiliam, 2005). Conventional assessment only emphasizes the assessment of practice questions without considering what needs to be corrected for students. 
Jurnal Prima Edukasia, 9 (1), 2021 - 81

Eri Yusron, Sudiyatno Sudiyatno

Then the variance in AfL learning outcomes and conventional assessment learning outcomes both provide classical and equitable treatment. In the application of AfL, the provision of facilities in providing identification and improvement of individual students makes AfL learning outcomes evenly distributed. As with conventional assessments, the variance of learning outcomes is evenly distributed. This is because giving classical treatment does not affect the diversity of learning outcomes (Rahmawati, 2018).

Another difference between the role of AfL and the application of conventional assessment lies in its role. The role of AfL in conducting the process of diagnosing students' abilities and needs is right in making improvements. So AfL provides training, but the training is used as a process of diagnosing students' abilities and needs. This process will assist the teacher in choosing the next steps to make appropriate and needed learning improvements.

The findings in the comparison of the role of assessment in the experimental and control classes led to the process of adjusting the questions carried out by students. The post-test students' results with the application of AfL showed that students could improve students' ability to answer questions systematically (Figure 1).

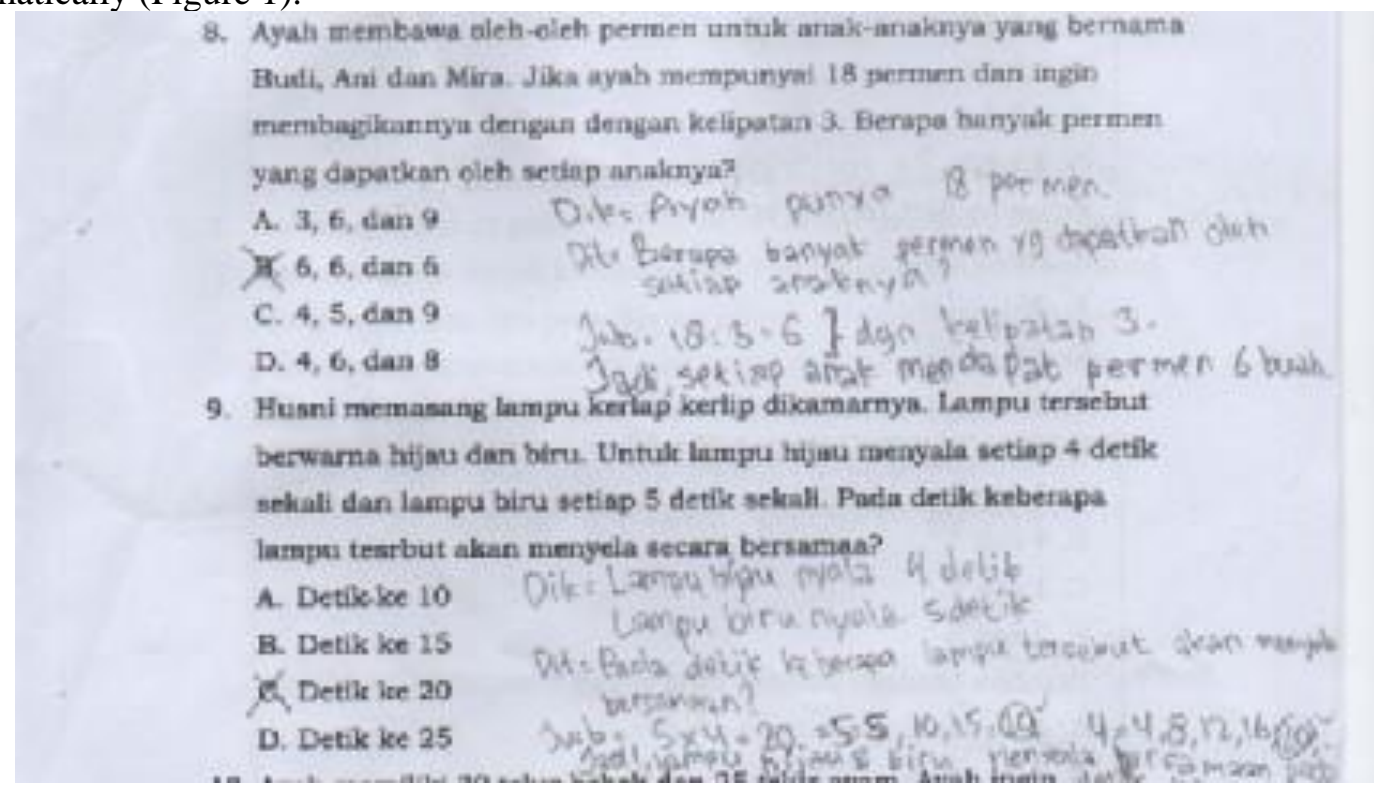

Figure 1. Experiment Class Post-test Results

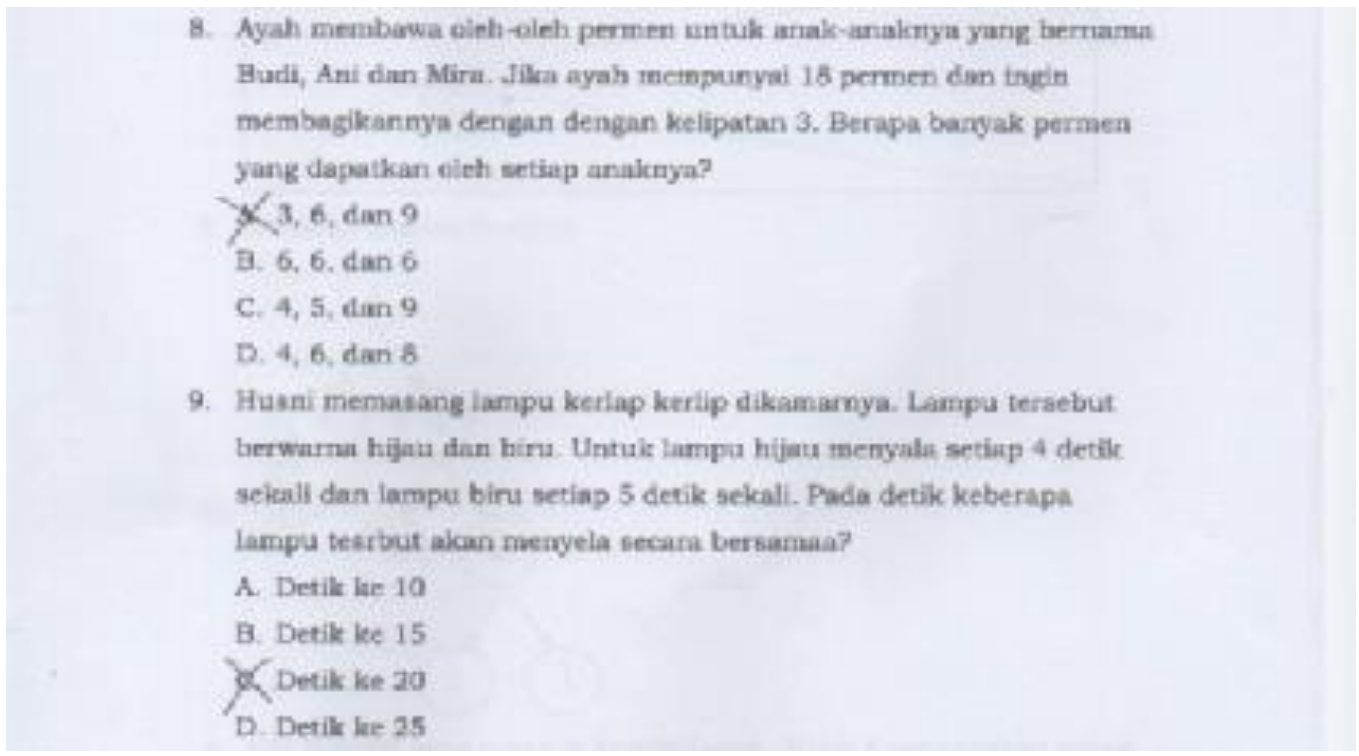

Figure 2. Control Class Posttest Results

Meanwhile, in the control class, students could not show systematic problem solving (Figure 1). These findings indicate that AfL can direct students to be able to solve problems systematically. 
Jurnal Prima Edukasia, 9 (1), 2021 - 82

Eri Yusron, Sudiyatno Sudiyatno

This finding is one of the differences between applying the assessment to the experimental and control classes. The difference in the application of assessment turns out to be in the learning outcomes and in solving the questions. There are differences between the experimental class and students. So, in the assessment application, it is necessary to diagnose needs in conducting the assessment. This is because it will help education in taking the next steps.

\section{Conclusion}

The implementation of AfL needs to convey identification of abilities, identification of achievements, improvement of achievements, conducting feedback on assessments, and follow-up on learning improvements. It is important to note, such as time management, instruments, communication, and coordination between students, parents, teachers, and schools. AfL is useful in the mathematics learning process. In the planning process, AfL facilitates students to participate in planning lessons. In the learning process, AfL allows students to be actively involved in the assessment. In the follow-up process, teachers and students make improvements and plan further learning.

Learning with the application of AfL in mathematics learning in elementary schools can improve student learning outcomes. Learning with the application of AfL does not affect differences in the variance of results before and after learning. Learning with the application of AfL is different from conventional assessors. In comparison, conventional assessment has not provided improvement for students to solve difficulties or needs in learning. There is no difference in variance in learning outcomes on AfL and conventional assessments.

Their several notes suggest. In the learning process with AfL, it is necessary to review the tools used and time management. This becomes an obstacle in the implementation of learning with AfL assessments on mathematics in elementary schools. The assessment was carried out to overcome obstacles in the process of implementing learning with AfL. For further research on the application of AfL assessment learning, it is necessary to explore the effect of learning outcomes. It needs other influences that can affect learning outcomes besides AfL. Research on the design development and assessment of the AfL tool is highly recommended. Because this will help the assessment process with AfL be more effective and efficient in time management, this can help educators assess with AfL.

\section{References}

Aiken, L. R. (1980). Content validity and reliability of single items or questionnaires. Educational and Psychological Measurement, 40(4), 955-959. https://doi.org/10.1177/001316448004000419

Arifin, S., Wahyudin, W., \& Herman, T. (2020). The effects of contextual group guided discovery learning on students' mathematical understanding and reasoning. Jurnal Prima Edukasia, 8(2), 106-114. https://doi.org/10.21831/jpe.v8i2.33059

Astuti, S. P. (2015). Pengaruh kemampuan awal dan minat belajar terhadap prestasi belajar fisika. Formatif: Jurnal Ilmiah Pendidikan MIPA, 5(1). https://doi.org/http://dx.doi.org/10.30998/formatif.v5i1.167

Atkin, J. M., \& Coffey, J. E. (2003). Everyday assessment in the science classroom. National Science Teachers Associatio Press.

Azwar, S. (2011). Reliabilitas dan validitas. Pustaka Belajar.

Baas, D., Castelijns, J., Vermeulen, M., Martens, R., \& Segers, M. (2015). The relation between Assessment for Learning and elementary students' cognitive and metacognitive strategy use. British Journal of Educational Psychology, 85(1), 33-46. https://doi.org/10.1111/bjep.12058

Baharun, H. (2015). Penerapan pembelajaran active learning untuk meningkatkan hasil belajar siswa di madrasah. Jurnal Pendidikan Pedagogik, 1(1), 34-39. https://doi.org/10.33650/pjp.v1i1.14

Benkirane, L., Hamza, M., Sbihi, W., \& Arabi, E. (2019). Perception of learning assessment methods by students at the end of their initial training at the faculty of dentistry of casablanca. Education Research International, 2019, 1-5. https://doi.org/10.1155/2019/8463169

Black, P., \& Wiliam, D. (1998). Assessment and classroom learning. Assessment in Education: Principles, Policy \& Practice, 5(1), 7-74. https://doi.org/10.1080/0969595980050102

Black, P., \& Wiliam, D. (2005). Inside the black box: Raising standards through classroom 
Jurnal Prima Edukasia, 9 (1), 2021 - 83

Eri Yusron, Sudiyatno Sudiyatno

assessment. Granada Learning.

Black, P., \& Wiliam, D. (2018). Classroom assessment and pedagogy. Assessment in Education: Principles, Policy \& Practice, 25(6), 1-25. https://doi.org/10.1080/0969594X.2018.1441807

Bluman, A. G. (2009). Elementary statistics: A step by step approach (7th ed.). McGraw-Hill Higher Education.

Chappuis, S., \& Stiggins, R. J. (2002). Classroom assessment for learning. Educational Leadership, 60(1), 40-43.

Clarke, B., Baker, S., Smolkowski, K., Doabler, C., Strand Cary, M., \& Fien, H. (2015). Investigating the efficacy of a core kindergarten mathematics curriculum to improve student mathematics learning outcomes. Journal of Research on Educational Effectiveness, 8(3), 303-324. https://doi.org/10.1080/19345747.2014.980021

DeLuca, C., Klinger, D., Pyper, J., \& Woods, J. (2015). Instructional rounds as a professional learning model for systemic implementation of assessment for learning. Assessment in Education: Principles, Policy \& Practice, 22(1), 122-139. https://doi.org/10.1080/0969594X.2014.967168

Enggarwati, N. S. (2015). Kesulitan guru SD Negeri Glagah dalam mengimplementasikan penilaian autentik pada Kurikulum 2013. Jurnal Pendidikan Guru Sekolah Dasar, 5(12), 1-8. http://journal.student.uny.ac.id/ojs/index.php/pgsd/article/view/1141

Gerritsen-van Leeuwenkamp, K. J., Joosten-ten Brinke, D., \& Kester, L. (2019). Students' perceptions of assessment quality related to their learning approaches and learning outcomes. Studies in Educational Evaluation, 63(July), 72-82. https://doi.org/10.1016/j.stueduc.2019.07.005

Harlen, W. (2007). Assessment of learning. A Sage Publiscations Ltd.

Heitink, M. C., Van der Kleij, F. M., Veldkamp, B. P., Schildkamp, K., \& Kippers, W. B. (2016). A systematic review of prerequisites for implementing assessment for learning in classroom practice. Educational Research Review, 17, 50-62. https://doi.org/10.1016/j.edurev.2015.12.002

Hevriansyah, P., \& Megawanti, P. (2017). Pengaruh kemampuan awal terhadap hasil belajar matematika. JKPM (Jurnal Kajian Pendidikan Matematika), 2(1), 37. https://doi.org/10.30998/jkpm.v2i1.1893

Irawati, R. K. (2015). Pengaruh model problem solving dan problem posing serta kemampuan awal terhadap hasil belajar siswa. Jurnal Pendidikan Sains, 2(4), 184-192. https://doi.org/10.17977/jps.v2i4.4534

Jeyaraj, J. S. (2019). Effective learning and quality teaching. SSRN Electronic Journal, 57(35), 30-35. https://doi.org/10.2139/ssrn.3486348

Khoiriah, K., Jalmo, T., \& Abdurrahman, A. (2020). Implementasi assessment for learning berbasis higher order thinking skills untuk menumbuhkan minat baca. Jurnal Inovasi Pendidikan IPA, 6(2). https://doi.org/10.21831/jipi.v6i2.22817

Kurniawan, D. (2016). Penggunaan assessment for learning (AFL) melalui peer assessment untuk meningkatkan mathematical problem solving. Jurnal Penelitian Pendidikan Dan Pengajaran Matematika, 2(2), 87-98. https://doi.org/10.37058/jp3m.v2i2.160

Larson, R., \& Farber, B. (2019). Elementary statistic: Picturing the world (5th ed.). Pearson College Division. https://www.pearsonhighered.com/assets/preface/0/1/3/4/0134684907.pdf

Lestari, K. E., Yudhanegara, M. R., \& Zarkasyi, W. (2015). Penelitian pendidikan matematika. PT Refika Aditama.

Mansyur, M. (2013). Pengembangan model assessment for learning pada pembelajaran matematika di SMP. Jurnal Penelitian Dan Evaluasi Pendidikan, 15(1), 71-91. https://doi.org/10.21831/pep.v15i1.1088

Mardapi, D. (2012). Pengukuran penilaian dan evaluasi pendidikan. Nuha Medika.

Miles, M. B., Huberman, A. M., Huberman, M. A., \& Huberman, M. A. (1994). Qualitative data analysis: An expanded sourcebook. SAGE Publications Ltd.

Mulyono, D. (2017). The influence of learning model and learning independence on mathematics learning outcomes by controlling students' early ability. International Electronic Journal of 
Jurnal Prima Edukasia, 9 (1), 2021 - 84

Eri Yusron, Sudiyatno Sudiyatno

Mathematics Education, 12(3), 689-708.

O’Leary, M. (2017). Measuring Teachers' Assessment for Learning (AfL) Classroom Practices in Elementary Schools. International Journal of Educational Methodology, 3(2), 103-115. https://doi.org/10.12973/ijem.3.2.103

Paolini, A. (2015). Enhancing teaching effectiveness and student learning outcomes. The Journal of Effective Teaching, 15(1), 20-33.

Paryanto, \& Sudiyatno. (2011). Implementasi Model Assessment for Learning (AFL) pada Pembelajaran Proses Pemesinan di Jurusan Pendidikan Teknik Mesin FT UNY. Jurnal Pendidikan Teknologi Dan Kejuruan, 20(1), 43-66.

Rahmawati, N. K. (2018). Penerapan Model Pembelajaran Matematika Menggunakan Model SAVI dan VAK Pada Materi Himpunan Terhadap Pretasi Belajar Siswa. Delta: Jurnal Ilmiah Pendidikan Matematika, 5(2), 21. https://doi.org/10.31941/delta.v5i2.549

Retnawati, H. (2016). Analisis Kuantitatif Instrumen Penelitian. Parama Publishing.

Retnawati, H., Hadi, S., Munadi, S., Hadiana, D., Muhardis, M., Apino, E., Djidu, H., Rafi, I., Yusron, E., \& Rosyada, M. N. (2019). When national examination no longer determining graduation, will students accomplish it seriously? Indonesian Journal of Educational Assesment (IJEA), 2(2), 4049. https://doi.org/10.26499/ijea.v2i2.34

Rohmawati, A. (2015). Efektivitas Pembelajaran. Jurnal Pendidikan Usia Dini, 9(1), 15-32.

Rosida, V., Taqwa, M., \& Kamaruddin, R. (2018). Efektivitas pendekatan etnomatika berbasis budaya lokal dalam pembelajaran matematika. HISTOGRAM: Jurnal Pendidikan Matematika, 2(2), 97107. https://doi.org/10.31100/histogram.v2i2.235

Sulistiyarini, D., \& Sukardi, S. (2016). The influence of motivation, learning styles, teacher leadership, and teaching intensity on students' leaning outcomes. Jurnal Pendidikan Teknologi Dan Kejuruan, 23(2), 136-143. https://doi.org/10.21831/jptk.v23i2.12296

Sutarto, J. (2017). Determinant factors of the effectiveness learning process and learning output of equivalent education. 3rd NFE Conference on Lifelong Learning, 88(Nfe 2016), 90-95. https://doi.org/10.2991/nfe-16.2017.22

Taras, M. (2010). Assessment for learning: Assessing the theory and evidence. Procedia - Social and Behavioral Sciences, 2(2), 3015-3022. https://doi.org/10.1016/j.sbspro.2010.03.457

Triwiyono, E. (2017). Pengembangan Assessment for Learning (AfL) melalui lesson study pada praktik pemesinan SMK Sesuai Kurikulum 2013. Jurnal Dinamika Vokasional Teknik Mesin, $2(1), 28-36$.

Widyastuti Nurharyanto, D., \& Retnawati, H. (2020). The difficulties of the elementaru school student in solving the mathematical narrative-type test item. Jurnal Prima Edukasia, 8(1), 29-39. https://doi.org/10.21831/jpe.v8i1.29969

Winarno, W., Zuhri, M., Mansur, M., Sutomo, I., \& Widhyahrini, K. (2019). Development of assessment for the learning of the humanistic model to improve evaluation of elementary school mathematics. International Journal of Instruction, 12(4), 49-64.

https://doi.org/10.29333/iji.2019.1244a

Yusron, E., Retnawati, H., \& Rafi, I. (2020). Bagaimana hasil penyetaraan paket tes USBN pada mata pelajaran matematika dengan teori respons butir? Jurnal Riset Pendidikan Matematika, 7(1), 112. https://doi.org/https://doi.org/10.21831/jrpm.v7i1.31221

Zajda, J. (2018). Motivation in the classroom: creating effective learning environments. Educational Practice and Theory, 40(2), 85-103. 